\title{
Cytological comparison of gill chloride cells and blood serum ion concentrations in kutum (Rutilus frisii kutum) spawners from brackish (Caspian Sea) and fresh water (Khoshkrood River) environments
}

\author{
Zahra Ghahremanzadeh, Javid Imanpour Namin, Ali Bani, Ali Hallajian
}

Received - 02 February 2014/Accepted - 15 May 2014. Published online: 30 September 2014; $\odot$ Inland Fisheries Institute in Olsztyn, Poland Citation: Ghahremanzadeh Z., Namin J.I., Bani B., Hallajian A. 2014 - Cytological comparison of gill chloride cells and blood serum ion concentrations in kutum (Rutilus frisii kutum) spawners from brackish (Caspian Sea) and fresh water (Khoshkrood River) environments - Arch. Pol. Fish. 22: 189-196.

\begin{abstract}
The size and number of chloride cells and serum ion concentrations in kutum, Rutillus frisii kutum Nordman, from brackish (Caspian Sea) and fresh water (Khoshkrood River) environments were studied to gain a better understanding of osmoregulation in this species. Twenty mature kutum specimens were collected from the Caspian Sea (Anzali coasts, $8.49 \mathrm{ppt}$ salinity and $12.4^{\circ} \mathrm{C}$ temperature) and 20 specimens from Khoshkrood River $(0.18$ ppt salinity and $18^{\circ} \mathrm{C}$ temperature). Gill samples were analyzed histologically and concentrations of $\mathrm{Na}^{+}, \mathrm{Cl}^{-}, \mathrm{K}^{+}$, and $\mathrm{Mg}^{2+}$ ions were determined in the blood serum. Concentrations of $\mathrm{Na}^{+}, \mathrm{Cl}^{-}, \mathrm{K}^{+}$, and $\mathrm{Mg}^{2+}$ ions and osmotic pressure in mature kutum from brackish water were significantly higher than in specimens from fresh water. The average size and number of chloride cells in the fish from seawater were considerably larger than those from fresh water. The mean size of chloride cells was $6.89 \pm 1.16 \mu \mathrm{m}$ in brackish water samples and $5.1 \pm$
\end{abstract}

Z. Ghahremanzadeh, J.I. Namin

Fisheries Department, Faculty of Natural Resources, University of Guilan, Sowmeh-sara, Iran

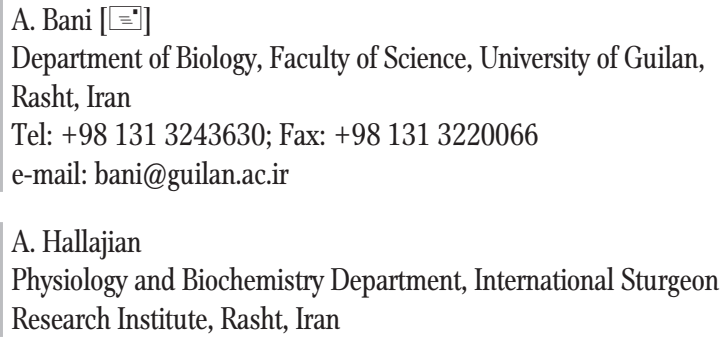

$0.81 \mu \mathrm{m}$ in river samples. The average number of chloride cells in brackish and river water samples were 16.92 and 6.57 , respectively. The density and size of chloride cells increased with increases in salinity.

Keywords: kutum, salinity, chloride cell, ion concentration, osmoregulation

\section{Introduction}

Salinity is a key factor influencing life, metabolism, and the distribution of fishes, and it affects their growth and developmental stages. The survival of fish species in a particular environment is dependent on the body's ability to cope with environmental salinity at different stages of life (Varsamos et al. 2002). Osmoregulation is a process that controls electrolyte concentrations and dissolved organic substances in body fluids and maintains the balance of salt and water (Jurd 2000). Gills are the most important osmoregulatory organs in euryhaline teleost fishes, and the gill epithelium is essential for the uptake and excretion of salt in fresh water and salt water, respectively (Evans et al. 2005). 
Gill chloride cells are responsible for $\mathrm{Na}^{+}$and $\mathrm{Cl}^{-}$ transfer. Chloride cells are also involved in the maintenance of blood acid-base balance and $\mathrm{Ca}^{2+}$ ion uptake (Kaneko et al. 2008). Therefore, chloride cells play a significant role in the process of adaptation to various osmotic and ionic environments. Chloride cells are present on the secondary lamellae, which is the interlamellar region of the gill filament (Altinok et al. 1998, Zydlewski and McCormick 2001). High activity and well-developed mitochondria enable these cells to produce the sufficient energy required for active ion transfer. Na-K-activated ATPase is the main enzyme in the active ion transfer of chloride cells (Shikano and Fujio 1999). Because of the large number of mitochondria present, they are also known as mitochondria-rich cells or MRC (McCormick 2011). Exposure to high salinity results in an increase in the number of chloride cells (Carmona et al. 2004) and $\mathrm{Na}^{+}-\mathrm{K}^{+}$-ATPase activity (Caberoy and Quinitio 2000). In contrast, the chloride cells of freshwater fish are reduced in number but can actively uptake salts from the water medium (Fielder et al. 2007).

Changes in chloride cell morphology and the number of cells are considered to be an adaptation strategy in response to different environmental salinity levels. Changes in chloride cell size and number have been studied in euryhaline species such as tilapia, Oreochromis mossambicus (Peters) (Foskett et al. 1981), guppy, Poecilia reciculata Peters (Pisam et al. 1995), and milkfish, Chanos chanos (Forsskíl) (Lin et al. 2003). However, further studies are required to foster a better understanding of osmoregulation and the role of chloride cells.

Rutilus frisii kutum belongs to the Cyprinidae family and is a native fish of the Caspian Sea. This species is euryhaline and migrates into fresh water during the spawning season. As a result, kutum is possibly capable of tolerating a wide range of salinities. This provides an excellent opportunity to study the osmoregulatory systems and osmoregulatory organs in this semi-anadromous fish that spawns in mid- to lower river segments (Sharyati 1993, Holcik 1995). Almost all previous studies focus on anadromous fish species like salmon that spawn in upper river segments. However, information on the physiological processes that regulate osmolality and electrolyte concentrations in semi-anadromous fishes is scarce. The purpose of this study is to compare the size and number of gill chloride cells and changes in serum ion concentrations in this species in brackish water (Caspian Sea) and in fresh water (Khoshkrood River). This will help us to understand more about chloride cell function during the transitory life history stage of spawners prior and subsequent to entering fresh water.

\section{Materials and methods}

\section{Fish sampling and laboratory processing}

In December 2009, 20 mature kutum (female:male ratio 1:1) with a total length of $46.55 \pm 5.76 \mathrm{~cm}$ (mean length \pm SE) were collected at the beach seine catch station of Bandar Anzali (037²7'48.06”N, 049 34'17.40”E), in the province of Guilan, Iran. Only healthy-looking specimens were selected for the study. The salinity of the Caspian Sea water at the time of sampling was 8.49 ppt. Additionally, 20 mature kutum ready for spawning (female:male ratio $1: 1)$ with a total length of $39.5 \pm 4.52 \mathrm{~cm}$ were caught in the Khoshkrood River (037 03 '13.44”N, $050^{\circ} 26^{\prime} 26.65$ ”E) in Guilan province in April 2010. The salinity of the water at the time of sampling was $0.18 \mathrm{ppt}$, and the physicochemical parameters differed from those of the sea water (Table 1). Fish

Table 1

Ionic composition and osmotic pressures of the Caspian Sea and the Khoshkrood River

\begin{tabular}{lll}
\hline \hline Parameter & Brackish water & Fresh water \\
\hline \hline Temperature $\left({ }^{\circ} \mathrm{C}\right)$ & 12.4 & 18 \\
$\mathrm{pH}$ & 8.53 & 5.25 \\
$\mathrm{Na}+\left(\mathrm{mEq} \mathrm{l}^{-1}\right)$ & 107.8 & 1.6 \\
$\mathrm{~K}+\left(\mathrm{mEq} \mathrm{l}^{-1}\right)$ & 1.85 & 0.15 \\
$\mathrm{Cl}-\left(\mathrm{mEq} \mathrm{l}^{-1}\right)$ & 120.4 & 0.9 \\
$\mathrm{Mg} 2+\left(\mathrm{mEq} \mathrm{l}^{-1}\right)$ & 35 & 0.61 \\
Osmotic pressure $\left(\mathrm{mEq} \mathrm{l}^{-1}\right)$ & 407 & 6 \\
\hline \hline
\end{tabular}


sampling in the river was undertaken $500 \mathrm{~m}$ upstream from the river inlet to the Caspian Sea. The sampled fish were adult male and female kutum migrating into the river for spawning.

The specimens were immediately anesthetized in a plastic tank (100 l) using clove powder (150 $\left.\mathrm{mg} \mathrm{l}^{-1}\right)$ mixed either with Caspian Sea or Khoshkrood River water for the sea or river specimens, respectively. Following anesthesia, $4 \mathrm{ml}$ blood samples were taken on site from the caudal vein using a sterile $5 \mathrm{ml}$ plastic syringe. Blood sampling was performed in less than 1 min for each fish. Blood samples were placed in a plastic tube, stored on ice, and transferred to the laboratory within one hour of their collection for further analysis including measurements of ionic parameters and osmotic pressures. At the end of blood samplings, gill tissue samples were taken from the second arch of both right and left gills (equal numbers of male and female fish). Tissue samples were preserved in a $4 \%$ formalin solution and transported to the laboratory for histological examinations.

The blood samples were centrifuged for $5 \mathrm{~m}$ (5000 rpm), and the isolated serum was removed and stored at $-20^{\circ} \mathrm{C}$ until it was used to determine ion concentrations (Singer et al. 2002). Serum $\mathrm{Cl}^{-}$and $\mathrm{Mg}^{2+}$ were determined with a RA-1000 device (Technicon, USA). The ions were measured using colorimetric methods in which the intensity of light absorption has a direct relationship with ion concentration. Serum $\mathrm{Mg}^{2+}$ was measured using the xylidyl blue method in which the xylidyl-Mg complex can be measured at 500-550 $\mathrm{nm}$. Chloride ions react with undissociated mercuric thiocyanate to form undissociated mercuric chloride and free thiocyanate ions. Thiocyanate ions react with ferric ions to form a highly colored reddish complex of ferric thiocyanate, the absorbance of which is proportional to the amount of chloride in the specimen, and it was measured at 500-550 nm. Na ${ }^{+}$and $\mathrm{K}^{+}$ions were measured using a flame photometer (Jenway, UK). The intensity of the flame color, which is proportional to the concentration of the element, was quantified by photoelectric circuitry. The tissues were dehydrated and embedded in paraffin wax for histological analyses (Akhundov and Federov 1995). The samples were then sectioned to a thickness of $6 \mu \mathrm{m}$ with a microtome (Leitz, 1512, Germany), and stained with hematoxylin and eosin (Hung et al. 1990). Histological slides were examined with the light microscopy method, and pictures were taken with a camera (Nikon, E-600). Ten fields were randomly selected on each slide, and each field area of 8-10 cells $\left(\mu \mathrm{m}^{2}\right)$ was examined and measured with Biocom Visolab image analyzer software. The numbers of gill chloride cells of the fish collected from fresh and brackish water were counted in ten sections of each slide and averaged.

\section{Statistical analysis}

Data normality was tested with Kolmogorov-Smirnov analysis. Two-way analysis of variance (two-way ANOVA) was used to compare the mean size of the chloride cells (as the dependent variable) in brackish and fresh water in both sexes (as the independent variable). Two-way ANOVA was used to compare the osmotic pressure and concentration of $\mathrm{Na}^{+}, \mathrm{Cl}^{-}, \mathrm{K}^{+}$, $\mathrm{Mg}^{2+}$ ions (dependent variables) in brackish and fresh water and in both sexes (independent variable). Finally, the Chi-square test was applied to compare the number of gill chloride cells in the sea and river samples. Differences of $\mathrm{P}<0.05$ were considered statistically significant.

\section{Results}

\section{Ion concentration and osmotic pressure}

The concentration of $\mathrm{Na}^{+}$and $\mathrm{Cl}^{-}$ions in kutum blood serum varied with changes in salinity (Fig. 1a), and the concentrations of $\mathrm{Na}^{+}$and $\mathrm{Cl}^{-}$ions in the blood serum were significantly lower in kutum captured in fresh water $\left(\mathrm{Na}^{+}: \mathrm{P}<0.05, \mathrm{Cl}^{-}: \mathrm{P}<0.05\right)$. Concentrations of $\mathrm{Na}^{+}(\mathrm{P}>0.05)$ and $\mathrm{Cl}^{-}(\mathrm{P}>0.05)$ in the blood serum were not significantly different between the sexes.

Significant differences were observed between concentrations of $\mathrm{K}^{+}$and $\mathrm{Mg}^{2+}$ ions in the blood 

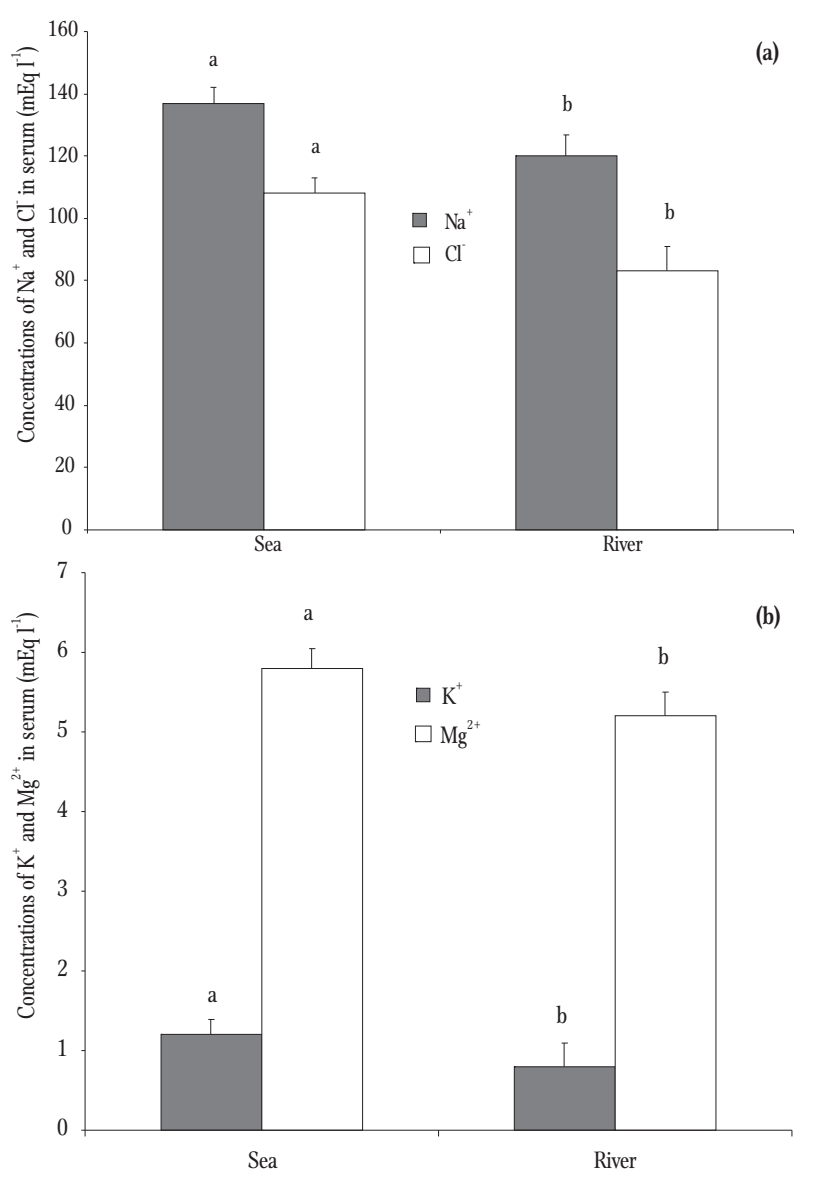

Figure 1. Concentrations of $\mathrm{Na}^{+}$and $\mathrm{Cl}^{-}(\mathrm{a}), \mathrm{K}^{+}$and $\mathrm{Mg}^{2+}$ (b) ions in blood the serum of kutum, Rutilus frisii kutum, from brackish and fresh water. Values are expressed as mean \pm SD $(n=20)$. Means tagged with different superscripts are significantly different $(\mathrm{P}<0.05)$ between the two environments.
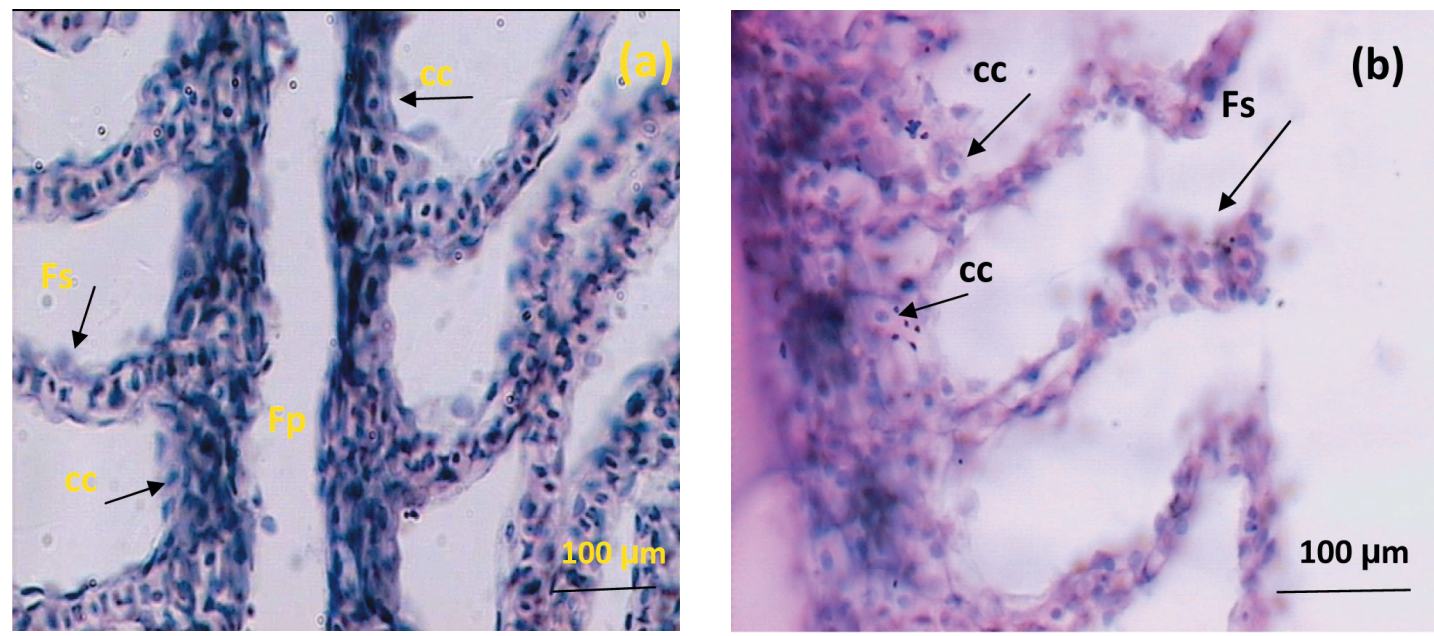

Figure 2. Section of gill tissue in kutum, Rutilus frisii kutum, from the Khoshkrood River (a) and the Caspian Sea. (b) primary gill filaments (Fp), Secondary gill filaments (Fs), Chloride cells (cc) (H \& E, 40 X) serum of kutum from the two environments $\left(\mathrm{K}^{+}: \mathrm{P}=\right.$ $\left.0.001, \mathrm{Mg}^{2+}: \mathrm{P}=0.003\right)$. The mean concentrations of $\mathrm{K}^{+}$and $\mathrm{Mg}^{2+}$ in the fish sampled from the Caspian Sea were greater than those caught from the Khoshkrood River (Fig. 1b). Fish sex had no significant effect on the concentrations of $\mathrm{K}^{+}$and $\mathrm{Mg}^{2+}$ ions in the blood serum of kutum $(\mathrm{P}>0.05)$.

The variation in the serum osmotic pressure was a function of salinity. Osmotic pressure in the sea $\left(383.21 \pm 14.78 \mathrm{mOsm} \mathrm{l}^{-1}\right)$ was higher than that in the river $\left(304.80 \pm 7.76 \mathrm{mOsm} \mathrm{l}^{-1}\right)(\mathrm{P}<0.05)$. Fish sex had no significant effect on blood serum osmotic pressure in kutum $(\mathrm{P}>0.05)$.

\section{Chloride cells}

The size of gill chloride cells in kutum varied in samples from the brackish water of the Caspian Sea and in those from the fresh water of the Khoshkrood River (Figs. 2a and 2b). A significant decrease in chloride cell diameter was observed in kutum captured in the Khoshkrood River $(\mathrm{P}<0.05)$. The mean diameter of gill chloride cells in specimens caught from the Caspian Sea was 1.8 times greater than in specimens entering the Khoshkrood River (Fig. 3). Fish sex had no significant effect on chloride cell size salinity $(\mathrm{P}<0.05)$. The mean number of chloride $(\mathrm{P}>0.05)$. The number of chloride cells varied with 


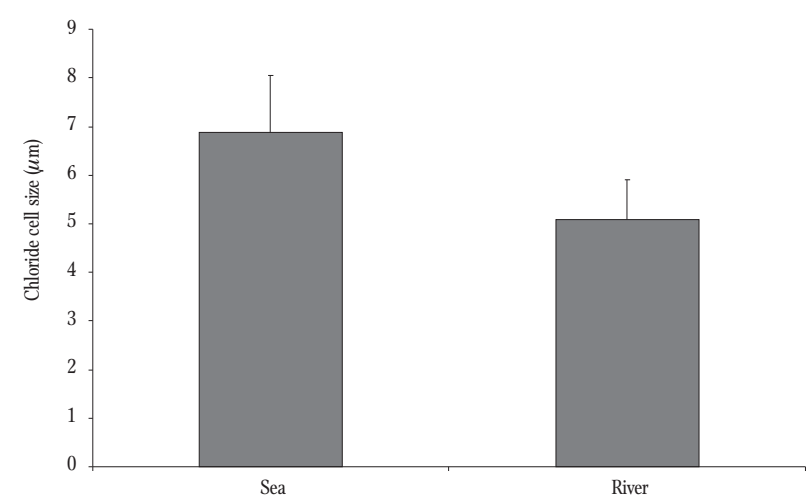

Figure 3. Mean size of gill chloride cells in kutum, Rutilus frisii kutum, from the Caspian Sea and the Khoshkrood River ( $\mathrm{n}=10$ ). Values are expressed as mean \pm SD.

cells in gills of fish caught from the sea and the river was 16.92 and 6.57 , respectively.

\section{Discussion}

Osmoregulation in mature kutum is a function of salinity and is reflected in the osmotic pressure of the plasma and in concentrations of sodium, chloride, potassium, and magnesium ions in the blood serum. A significant decrease in plasma osmotic pressure was observed when mature kutum migrated into fresh water during the spawning period. The results obtained in the present study on kutum blood serum osmotic pressure were similar to studies on euryhaline teleost fishes such as Chelon labrosus (Risso) (Lasserre 1971) and Ch. chanos (Lin et al. 2003). Osmotic pressure in marine stenohaline fish varies between 370-480, while in fresh water stenohaline teleosts it is between 260-330 $\mathrm{mOsm} \mathrm{l}^{-1}$ (Jobling 1995). The osmotic pressure of the blood serum of kutum from the freshwater river was 304.80 $\mathrm{mOsm} \mathrm{l}^{-1}$ and $383.21 \mathrm{mOsm} \mathrm{l}^{-1}$ in those from the Caspian Sea water, which lies within in the range of fresh water and sea water teleost species and suggests that kutum is a euryhaline species capable of adjusting the osmotic pressure of its blood serum to inhabit the brackish environment of the Caspian Sea. Our results showed that following kutum migration into fresh water, the fish maintained blood serum osmotic pressure well above the ambient osmotic pressure, while in Caspian Sea water it was lower than that in the surrounding environment.

The mean concentration of $\mathrm{Cl}^{-}$ion in the serum showed decreasing trends following migration into fresh water. In a study by Sampaio and Bianchini (2002) on euryhaline flounder, Paralichthys orbignyanus (Val.), the concentration of sodium and chloride ions in sea water samples were 160 and 232 $\mathrm{mEq}^{-1}$ and in fresh water ones they were 226 and $131 \mathrm{mEq}^{-1}$, respectively. Piermarini and Evans (1998) studied concentrations of sodium and chloride ions in the blood serum of Atlantic stingrays, Dasyatis sabina (Lesueur), and reported that ion concentrations in seawater samples were significantly higher than in freshwater ones. According to Vonck et al. (1998), high concentrations of $\mathrm{Na}^{+}$and $\mathrm{Cl}^{-}$in seawater could have resulted in the transfer of these ions into the fish bodies.

The potassium concentration in the kutum blood serum was significantly reduced following migration into fresh water. In a study by Fielder et al. (2007), the serum concentrations of $\mathrm{Na}^{+}$and $\mathrm{Cl}^{-}$decreased following a rapid transfer from a salinity of $30 \mathrm{ppt}$ to one of $15 \mathrm{ppt}$, while there were changes in concentrations of $\mathrm{K}^{+}$. Concentrations of $\mathrm{Na}^{+}, \mathrm{Cl}^{-}$and $\mathrm{Mg}^{2+}$ in the blood serum of Mozambique tilapia (Vonck et al. 1998) and puffer fish (Lin and Lee 2005) in sea water were higher than in fresh water, while concentrations of $\mathrm{K}^{+}$in the blood serum of freshwater fish was higher than in marine species.

The pattern of changes in blood serum magnesium ion content in kutum was similar to that of other ions. Magnesium ion concentrations in the blood serum of kutum from brackish waters was $5.81 \mathrm{mEq}^{-1}$ and in those from fresh water was 5.081 $\mathrm{mEq}^{-1}$. Farabi et al. (2009) examined ion concentrations in the plasma of juvenile Russian sturgeon, Acipenser gueldenstaedtii Brandt \& Ratzeburg, from three different salinities, e.g., fresh water (5 ppt), estuarine water (9.5 ppt), and Caspian Sea water (12.5 ppt), and suggested that plasma concentrations of $\mathrm{Na}^{+}, \mathrm{K}^{+}$and $\mathrm{Mg}^{2+}$ ions in estuarine waters were higher than concentrations in fresh water and lower than Caspian Sea water. 
Elevated osmotic pressure and electrolyte concentrations in the blood serum of kutum spawners from brackish water results from the osmotically-induced removal of water from fish and the uptake of ions from the hyperosmotic environment into the fish (Bath and Eddy 1979, Alderdice 1988, Hwang et al. 1989). On the other hand, decreased osmotic pressure of blood serum and electrolytes in freshwater specimens results from the osmotically-induced entry of water into fish and the excretion of ions in the opposite direction (Alderdice 1988). Despite the fact that osmotic pressure and ion concentrations decreased significantly in kutum from fresh water in comparison to those from the Caspian Sea, a corresponding decrease did not occur in the blood serum of kutum in fresh water, which suggests that kutum are capable of osmotic regulation.

The large size of chloride cells in kutum caught in the Caspian Sea reflects the higher exchange of monovalent ions through these cells that enables this species to tolerate the salinity of the Caspian Sea. Size, density, distribution, and structure of chloride cells and $\mathrm{Na}^{+}-\mathrm{K}^{+}$-ATPase enzyme activity varies in response to different salinities (Uchida et al. 2000, Lee et al. 2000, Wilson et al. 2000, Tang et al. 2008). A positive correlation between salinity and chloride cell size has been reported in some fish species like Capoeta tinca (Heckel) (Erkmen and Kolankaya 2000), Ch. chanos (Lin et al. 2003), P. reticulatas (Evans et al. 2005, Belda and Kolankaya 2009), and Pagrus auratus (Forster) (Fielder et al. 2007). As $\mathrm{Na}^{+}-\mathrm{K}^{+}$-ATPase activity in gills is correlated with chloride cell size (Zydlewski and McCormick 2001), the large chloride cells in the kutum caught in the Caspian Sea suggest the higher activity of $\mathrm{Na}^{+}-\mathrm{K}^{+}$ ATPase.

Chloride cells have different functions in fish adapted to fresh water and seawater. In seawater, chloride cells are involved in the excretion of excessive ions, while in fresh water they are responsible for ion uptake in order to compensate for ion loss in hypoosmotic environments (Evans et al. 2005). The number of chloride cells can also change with variations in environmental salinity. The number of chloride cells in kutum specimens caught in Caspian Sea water was $61 \%$ higher than in kutum caught in freshwater. Following migration into a fresh water environment, a significant decrease was observed in the number of chloride cells. The high number of gill chloride cells in specimens from the sea reflects the greater requirement of these individuals for ion transport through these cells. Marshall and Nishioka (1980), in their study on Gillichthys mirabilis Cooper, placed the fish in water with a salinity as twice as high as the initial salinity, and they noted that higher salinity resulted in an increased number of chloride cells. However, in other fish species such as Nile tilapia (Guner et al. 2005) a different strategy was deployed following the transfer of the fish to saltwater where the number of chloride cells decreased while their size increased. The reduction in the size and number of chloride cells in kutum following migration into fresh water represents a reduction of their requirement for the active excretion of $\mathrm{Na}^{+}$and $\mathrm{Cl}^{-}$in hypoosmotic environments (Feilder et al. 2007). The results obtained in the present study showed that the large size and the number of chloride cells in seawater specimens were necessary for the active excretion of salt into the seawater (Ucida and Kaneko 1996, Wales 1997, Hirai et al. 1999).

Comparing the values obtained for osmotic pressure and ion concentrations of blood serum of kutum from the Caspian Sea and fresh water, one can conclude that kutum is hypoosmotic in the sea and hyperosmotic in fresh water during the different phases of its life cycle. This species uses special osmoregulation mechanisms during its migration from brackish to fresh water including changes in the size and number of gill chloride cells.

Acknowledgments. The authors are grateful to all colleagues at the Department of Physiology of Dr. Dadman International Sturgeon Research Institute, Iran. Special thanks go to Yalda Hooshyar for her valuable assistance with the acquisition of data. We wish to acknowledge Oma Arshad for her assistance in editing the English language text of this manuscript. This research was supported by the University of Guilan. 
Author contributions. A.B. supervised all stages, from the beginning to the end, of this research project; Z.G. preformed the experiment, collected data, and contributed by providing the preliminary draft of the manuscript; J.I.N. made a substantial contribution to this project during drafting and revising the manuscript critically for important intellectual content; A.H. preformed cytological analysis and laboratory work.

\section{References}

Alderdice D.F. 1988 - Osmotic and ionic regulation in teleost eggs and larvae - In: Fish Physiology Vol 11 (Eds) W.S. Hoar, D.J. Randall, Academic Press, San Diego: 163-251.

Altinok I., Galli S.M., Chapman F.M. 1998 - Ionic and osmotic regulation capabilities of juvenile Gulf of Mexico sturgeon, Acipenser oxyrinchus de sotoi - Comp. Biochem. Physiol. Part A. 120: 609-616.

Akhundov M. M., Fedorov K.Y. 1995 - Effect of exogenous estradiol on ovarian development in juvenile sterlet, Acipenser ruthenus - J. Ichthyol. 35: 109-120.

Bath R.N., Eddy F.B. 1979 - Salt and water balance in rainbow trout (Salmo gairdneri) rapidly transferred from fresh water to sea water - J. Exp. Biol. 83: 193-202.

Belda E., Kolankaya D. 2009 - The relationship between chloride cells and salinity adaptation in the euryhaline teleost, Lebistes reticulatus - J. Anim. Vet. Adv. 8: 888-892.

Caberoy N.B., Quinitio G.F. 2000 - Changes in $\mathrm{Na}+, \mathrm{K}+$-ATPase activity and gill chloride cell morphology in the grouper Epinephelus coioides larvae and juveniles in response to salinity and temperature - Fish. Physiol. Biochem. 23: 83-94.

Carmona R., García-Gallego M., Sanz A., Domezaín A., Ostos-Garrido M.V. 2004 - Chloride cells and pavement cells in gill epithelia of Acipenser naccarii: ultrastructural modifications in seawater-acclimated specimens - J. Fish Biol. 64: 553-566.

Erkmen B., Kolankaya D. 2009 - The relationship between chloride cells and salinity adaptation in the euryhaline teleost, Lebistes reticulatus - J. Anim. Vet. Adv. 8: 888-892.

Evans D.H., Piermarini P.M., Choe K.P. 2005 - The multifunctional fish gill: dominant site of gas exchange, osmoregulation, acid-base regulation, and excretion of nitrogenous waste - Physiol. Rev. 85: 97-177.

Farabi S.M.V., Najafpour S., Najafpour G.D. 2009 - Aspect of osmotic-ions regulation in juvenile ship, Acipenser nudiventris (Lovetsky, 1828) in the southeast of Caspian Sea - W. Appl. Sci. J. 7: 1090-1096.
Fielder D.S., Allan G.L., Pepperall D., Pankhurst P.M. 2007 The effects of changes in salinity on osmoregulation and chloride cell morphology of juvenile Australian snapper, Pagrus auratus - Aquaculture 272: 656-666.

Foskett J.K., Longsdon C.D., Turner T., Machen T.E., Bern H.A. 1981 - Differentiation of the chloride extrusion mechanism during seawater adaptation of a teleost fish, the cichlid Sarotherodon mossambicus - J. Exp. Biol. 93: 209-224.

Guner Y., Ozden O., Cagirgan H., Altunok M., Kizak V. 2005 - Effects of salinity on the osmoregulatory functions of the gills in Nile Tilapia (Oreochromis niloticus) - Turk. J. Vet. Anim. Sci. 29: 1259-1266.

Hirai N., Tagawa M., Kaneko T., Seikai T., Tanaka M. 1999 Distributional changes in branchial chloride cells during freshwater adaptation in Japanese Sea Bass Lateolabrax japonicus - Zool. Sci. 16: 43-49.

Holčik J. 1995 - New data on the ecology of kutum, Rutilus frisii (Nordmann, 1840) from the Caspian Sea - Ecol. Freshw. Fish. 4: 175-179.

Hung S.S., Groff J.M., Lutes P.B., Fynn-Aikins F.K. 1990 Hepatic and intestinal histology of juvenile white sturgeon fed different carbohydrates - Aquaculture 87: 349-360.

Hwang P.P., Sun C.M., Wu S.M. 1989 - Changes in plasma osmolality, chloride concentration and gill Na-K-ATPase activity in tilapia Oreochromis mossambicus during seawater acclimation - Mar. Biol. 100: 295-299.

Jobling M. 1995 - Environmental biology of fishes - Chapman \& Hall, London. 455 p.

Jurd R.D. 2000 - Instant Notes in Animal Biology - Bios. Sci. Pub.

Kaneko T., Hiroi J. 2008 - Osmo and ionoregulation - In: Fish Larval Physiology (Eds) R.N. Finn, B.G. Kapoor, Science Publishers, Enfield: 163-183.

Lasserre P. 1971 - Increase of $\left(\mathrm{Na}^{+}+\mathrm{K}^{+}\right)$- dependent ATPase activity in gills and kidneys of two euryhaline marine teleost, Crenimugil labrosus (Risso, 1826) and Dicentrarchus labrax (Linnaeus, 1758), during adaptation to freshwater - Life Sci. 10: 113-119.

Lee T.H., Feng S.H. Lin C.H., Hwang Y.H., Huang C.L., Hwang P.P. 2003 - Ambient salinity modulates the expression of sodium pumps in branchial mitochondria-rich cells of Mozambique tilapia, Oreochromis mossambicus - Zool. Sci. 20: 29-36.

Lin C.H., Lee T.H. 2005 - Sodium or potassium ions activate different kinetics of gill $\mathrm{Na}, \mathrm{K}$ - ATPase in three seawater and freshwater - acclimated euryhaline teleosts - J. Exp. Zool. Part A 303: 57-65.

Lin Y.M., Chen C.N., Lee T.H. 2003 - The expression of gill $\mathrm{Na}$, K-ATPase in milkfish Chanos chanos, acclimated to seawater, brackish water and fresh water - Comp. Biochem. Physiol. Part A 135: 489-497. 
Marshall W.S., Nishioka R.S. 1980 - Relation of mitochondria-rich chloride cells to active chloride transport in the skin of a marine teleost - J. Exp. Zool. 214: 147-156.

McCormick S.D. 2011 - The hormonal control of osmoregulation in teleost fish - In: Encyclopedia of fish physiology: from genome to environment (Ed.) A.P. Farrell, Academic Press, San Diego: 285-315.

Piermarini P.M., Evans D.H. 1998 - Osmoregulation of the Atlantic stingray (Dasyatis sabina) from the freshwater Lake Jesup of the St. Johns River, Florida - Physiol. Zool. 71: 553-560.

Pisam M., Moal C.L., Auperin B., Prunet P., Rambourg A. 1995 - Apical structures of "mitochondria-rich" $\alpha$ and $\beta$ cells in euryhaline fish gill: Their behavior in various living conditions - Anat. Rec. 241: 13-24.

Sampaio L.A., Bianchini A. 2002 - Salinity effects on osmoregulation and growth of the euryhaline flounder Paralichthys orbignyanus - J. Exp. Mar. Biol. Ecol. 269: 187-196.

Singer T.D., Clements K.M., Semple J.W., Schulte P.M., Bystrainnsky J.S., Finstad B., Fleming I.A., McKinley R.S. 2002 - Seawater tolerance and gene expression in two strains of Atlantic salmon (Salmo salar) smolts - Can. J. Fish. Aqua. Sci. 59: 125-135.

Sharyati A. 1993 - Fishes of the Caspian Sea Region - Iranian Fisheries Company, Iran (in Persian).

Shikano T., Fujio Y. 1999 - Relationships of salinity tolerance to immunolocalization of $\mathrm{Na}^{+}, \mathrm{K}^{+}$ATPase in the gill epithelium during seawater and freshwater adaptation of the Guppy, Poecilia reticulata - Zool. Sci. 15: 35-41.

Uchida K., Kaneko T. 1996 - Enhanced chloride cell turnover in the gills of chum salmon fry in seawater - Zool. Sci. 13: 655-660.

Uchida K., Kaneko T., Yamauchi K., Hirano Y. 2000 Morphometrical analysis of chloride cell activity in the gill filament and lamellae and changes in $\mathrm{Na}+, \mathrm{K}+$ -ATPase activity during seawater adaptation in chum salmon fry - J. Exp. Zool. 276: 193-200.

Varsamos S., Diaz J.P., Charmantier G., Flik G., Blasco C., Connes R. 2002 - Branchial chloride cells in sea bass (Dicentrarchus labrax) adapted to fresh water, seawater and doubly concentrated seawater - J. Exp. Zool. 293: 12-26.

Vonck A.P.M., WendelaarBonga A.S.E., Flik G. 1998 Sodium and calcium balance in Mozambique Tilapia, Oreochromis mossambicus, raised at different salinities Comp. Biochem. Physiol. Part A 119: 441-449.

Wales B. 1997 - Ultrastructural study of chloride cells in the trunk epithelium of larval herring, Clupea harengus Tiss. Cell. 29: 439-447.

Wilson J.M., Morgan J.D., Vogl A.W., Randall D.J. 2002 Branchial mitochondria-rich cells in the dogfish Squalus acanthias - Comp. Biochem. Physiol., Part A. 132: 365-374.

Zydlewski J., McCormick S.D. 2001 - Developmental and environmental regulation of chloride cells in young American Shad, Alosa sapidissima - J. Exp. Zool. 290: 73-78. 